\title{
Why We Can't Afford to be Innocent
}

\author{
Boaventura de Sousa Santos
}

Though different in style and approach these three texts have much in common. Even if mentioned explicitly only in Reyna, the debate on the modern versus the postmodern is present in all of them; all of them question the validity of modern scientific knowledge, as well as the dichotomy of subject/object that makes privileged validity claims possible; all of them are keenly aware of the cultural, political, and institutional embeddedness of modern science; finally, the theme of the Cold War and of Cold War science is present in all of them.

In spite of all these convergences, however, there are significant differences among the three papers. While Price and Hancock present a critique of modem science, Reyna criticizes Geertz's postmodern science from a modernist viewpoint. While, for Price, the Cold War political establishment and its current reincarnations define populations and themes as objects of imperialist intervention which the Cold War scientific establishment transforms into objects of scientific inquiry, for Hancock, both the relation between subject and object and the process of intervention are more complex, since neither of them can operate without the active cooperation of the "object" or the "intervened." On the one hand, the subject/object relation is mediated by the presence of the "indigenous scholar," who is both a subject and an object of knowledge, a form of personalized authentic native knowledge provided by someone that is simultaneously an informant or student and a professor. On the other hand, the Cold War politico-scientific intervention is made possible by the active participation of local elites, interested in converting their specific kind of nationalism into the (general)

Identities, Vol 4(3-4), pp. 529-533 Reprints available directly from the publisher Photocopying permitted by license only
O 1998 OPA (Overseas Publishers Association) N.V. Published by license under the Cordon and Breach Publishers imprint. Printed in India 
kind of nationalism legitimized by international hegemonic science. For Reyna, the distinction between subject and object is not part of the politics of the modern science. On the contrary, the collapse of subject and object in Geertz's postmodernism allows for the uncontrolled objectification and ethical neutralization of massive human suffering.

Another contrast may be mentioned between Price and Hancock, on one side, and Reyna, on the other. Price and Hancock are mainly concerned with the power relations that preside over the organization and institutionalization of modern science. Such power relations occur at the international level and allow for the hegemonic country emerging out of WW II, the United States, to promote a hegemonic science at one time imperial vis-à-vis the interests of object-nations and docile vis-à-vis domestic interests. In a sense, imperial politics-which in Hancock's case is more complex (and more ambiguous) than in Price's, since for her area studies are both part of the Cold War and a liberal pluralistic counterpart to the Cold War-is the super-subject that objectifies anthropologists while transforming them into efficient subjects. For Reyna, the institutional or even cultural embeddedness of scientific knowledge is not the main issue. The main issue is an epistemological one, the choice between validated knowledges that allow for "approximate truths" and non-validated knowledges that lead to "regimes of truth," that is, to possible lies.

The three articles raise some of the most important debates about modern science at the end of the millenium. Is modern science culturally and politically embedded? Is it possible to disentangle the institutionalized processes of production of science from the science produced? Is epistemology an autonomous inquiry into the conditions of validity of knowledge or rather a form of politics designed to establish and legitimize hierarchies among rival knowledges? Are there alternative ways of knowing, and if so, is it possible to identify them without destroying their integrity? If modern science is nothing but the hegemonic epistemological paradigm, are there any signs of crisis of hegemony? Is there on the horizon an emergent new paradigm or paradigms?

Anyone who has done research outside the US and funded by a US institution knows how difficult it is to traverse the institutional thickness of mainstream social science without losing sight of the fact that the North's well-being is the South's burden and that science is ever the Great Unifier standing guard over this equation. 
Why We Can't Afford to be Innocent 531

All of us have stories to tell. My own, as a researcher doing participant observation in Rio's squatter settlements in the seventies for a Ph.D. at Yale University, is one among a multitude (Santos 1995: Chapter-Three-In-The-Mirror). Both Price and Hancock are aware that the command economy of science underlying the free market of scientific routine interaction is not a thing of the past. Price ponders that "if anything, it would appear that the US's National Security State is pausing to identify or create a new enemy for a menu of "outlaw nations, anti-naturalist groups, or religious movements opposing US economic interests" (p. 26). To my mind, there is no such pausing; indeed the new enemy are the illicit drugs-producing countries, those that oppose the US intellectual property rights policy concerning biodiversity, and in general those that seek to confront free trade with fair trade. Hancock, in her turn, is aware of the fact that the transition from an international economy to a global economy is certainly one factor behind the doom of area studies programs: "Programs of international studies, promising the knowledge required for participation in new, globalizing systems of production and consumption, are surfacing alongside of (and at times, in place of) older, area studies programs. Not coincidentally, the institutional autonomy and very existence of area studies programs are increasingly under threat" (p. 31). You need only think of the newest policy of the Ford Foundation concerning area studies, known as the initiative "Crossing Borders: Revitalizing Area Studies."

What is interesting about our institutional moment is that the proliferation of scientific knowledge that first led to the multiplication of disciplines is now undermining the disciplinary divisions of science. It is becoming increasingly clear that the latter, being intellectually bankrupt, owe their survival to nothing else than institutional inertia. The discredit of the disciplines and the fragmentation of knowledges make possible the bricolages and the mestiçajes among knowledges where resistances may emerge and alternatives may be made credible. Ours is not a simple moment of oppression and victims; it is a moment of a double crisis of regulation and emancipation, where the turbulence of scales and the bifurcations manifest themselves through the chaotic proliferation of realistic utopias.

Today we are living in turbulent times, a turbulence that manifests itself through a chaotic confusion of scales among phenomena. Urban violence is in this respect paradigmatic. When a street kid is 
looking for shelter to spend the night and is for that reason murdered by a policeman, or when a person is approached in the street by a beggar, refuses to give money, and is for that reason murdered by the beggar, what happens is an unpredictable explosion of the scale of the conflict: a seemingly trivial phenomenon seemingly without consequences is equated with another onesuddenly dramatic and full of consequences. This abrupt and unpredictable change in the scale of phenomena occurs today in all the various domains of social praxis, and that is why I dare to consider it as one of the basic features of our time (Santos 1996: 11). Following Prigogine (1980; Prigogine and Stengers 1979), I believe that our societies today are characterized by bifurcation. Bifurcation occurs in unstable systems whenever a minimal change can bring about qualitative changes in an unpredictable and chaotic way. This sudden scale explosion creates a tremendous turbulence and leaves the system in a state of irreversible vulnerability. I believe that the turbulence of our time is of this kind, and that in it resides the vulnerability affecting all forms of subjectivity and sociability, from labor to sexual life, from citizenship to ecosystem.

This would lead us to address the epistemological questions that are paramount in Reyna's article. Reyna tries to strike a third way in the modern/postmodern debate, but in my view without much success. Indeed, to my mind, the epistemological discussion in the first part of the article does not add substantially to the very well argued and compelling case he presents in the second part of the paper. He resorts to Jameson, who, in my opinion, is sometimes as modernist as a postmodernist can be and at other times as postmodernist as a modernist can be. He also resorts to Foucault, but his interpretation of Foucault, though interesting, raises many problems. For Foucault there are no truths or approximate truths outside the "regimes of truth." It means of course that all knowledge is socially constructed, but not that "anything goes." Inside the rhetorical communities there are reasonable ways of distinguishing between more and less credible forms of knowledge.

In my view, the problem does not lie so much in deciding between a modern and a postmodern epistemology as in deciding between a conservative or an oppositional social construction of knowledges. Contrary to a conservative postmodernism, oppositional postmodernism does not discard the importance of modern social problems. Contrary to a modernist epistemology, oppositional postmodernism does not believe in the efficacy or even 
Why We Can't Afford to be Innocent 533

feasibility of modern solutions for such problems. Oppositional postmodernism starts, thus, from the idea that our condition is a complex one, a condition in which we are facing modern problems for which there is no modern solution. Geertz, as much as Rorty, Lyotard, and Baudrillard, fails to confront this condition and in so doing falls into a conservative postmodernism. The alternative, however, is neither modern positivism nor Habermasian communicative action. There are too many silences, silencings, and epistemicides in the world for us to believe in unproblematic validations of knowledge and in ideal communicative encounters.

\section{NOTES}

Boaventura de Sousa Santos

University of Coimbra

Centro de Estudos Sociais

Apartado 3087

3000 Coimbra

Portugal

bsantos@gemini.ci.uc.pt

BOAVENTURA de SOUSA SANTOS is a professor of sociology in the Sociology Department of the School of Economics of the University of Coimbra and holds a joint appointment through the University of Wisconsin-Madison Law School and Sociology Department. He is also the director of the Center for Social Studies of the University of Coimbra. He is the author of Toward A New Common Sense: Law, Science and Politics In The Paradigmatic Transition (New York: Routledge 1995).

\section{REFERENCES CITED}

Prigogine, I.

1980 From Being to Becoming. San Francisco: Freeman.

Prigogine, I., and I. Stengers

1979 La nouvelle alliance: Metamorphoses de la science. Paris: Gallimard.

Santos, Boaventura de Sousa

1995 Toward a New Common Sense: Law, Science, and Politics in the Postmodern Transition. New York, Routledge.

1996 The Fall of the Angelus Novus: Beyond the Modern Game of Options and Roots. Working Paper Series on Political Economy of Legal Change, No. 3. Global Studies Program: University of Wisconsin-Madison. Forthcoming in Current Sociology. 